消化管出血に対するレーザー止血法

\title{
Endoscopic Laser Coagulation of gastrointestinal Hemorrhage
}

“原田一道 ${ }^{*}$ ，水島和壀，並木正義 葛西 真一**，水戸廸郎

K. Harada * K. Mizushima, M. Namiki, S. Kasai ${ }^{* *}$, M. Mito

* 旭川医大第三内科

** 旭川医大第二外科

* $\quad 3 r d$ Dept, of Internal Medicine Asahikawa Medical College.

** 2rd Dept, of Surgery Asahikawa Medical College.

\section{A abstract}

In this paper are described the results of fundamental and clinical investigations of controlling bleeding from the digestive tract.

As a fundamental research we were able to check bleeding of the mucosa artificially brought about in a dog when we irradiated laser to it. As there were some cases in which we were unable to control completely bleeding, an output of more than $45 \mathrm{~W}$ was considered necessary. The effect of the control of bleeding according to the amount of blood flow and its velocity.

On the basis of the above-mentioned fundamental results we applied them to clinical cases.

In those disease such as stress ulcer, where the blood vessels of the lesion are not exposed, bleeding was controlled with relative case by laser irradiation. We believe it is especially indicated for bleeding from stress ulcer. On the other hand, arterial bleeding of gastric ulcer can be managed at least for the time being, but of hemorrhage could not be expected sufficiently. It was especially difficult to control bleeding from the arteries more than $2 \mathrm{~mm}$ in diameter.

We have investigated the hemostatic procedure which combined the photocoagulation by the laser-coagulator with the endoscopic local injections of the hypertonic sodiumiepinephrin solution, in order to attain more effective hemostasis on the hemorrhagic lesions of the stomach.

We are testing the guartz fiber which was specifically designed for the usage for the common lateral view-type of endoscopy. 


\section{Iはじめに}

消化管出沿に対するレーザー光楾による内視 鏡的止血法については，1970年頃より酉ドイツ やアメリカなどから報告されている。

遅ればせながら，最近わが国においてもこれ についての関心が高まり，われわれも 3 年前か ら酶独M B B 社のY A Gレーザー (Medilas) を用いて、コアグレーターとしての基礎的およ

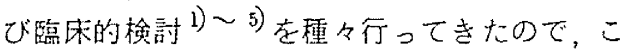
れまでの経験をもとに見解を述へる。

\section{II 基楚的研究の概要}

レーザー内視鏡の第一の適応はなんといって も消化管出血に対する止血である。踇床の実際 に用いる前に，安全性，効果的止血条件，その 他についてイヌを用いて実験してみたが，詳細

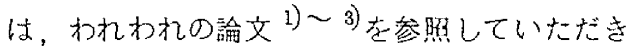
たい。琶点は，確実な止血効果を期待するには， 出力として $45 W$ 以を要し，かつ間歇的，短時 間照射がよく，照射方法としては，始め血管の 根元から，そして最後に中心部に照射するのが 効果的であること，また照射部位における血液 の除去が止血効果を得る上に非常に大事であり， さらに血流速度や血流量が止血效果に影橴する ことなどがわかった。

\section{III 臨床例における止血効果}

具体的な臨床例を呈示しながら，その効果と 問題点などを述べる。

症例 1.48藏，男性，ストレス渱崲

職業は公務員で，仕事上の問題と転勤がから み，心身ともに疲れはてたある日，激しい心茼 部痛とともにタール便をみたため当科を受診し たもので，直ちに胃内視鏡検查を行ったところ， 胃内に多量の血液が眝留し，周角から胃体部に かけ不整形の浅い出血性の掯瓷が多発していた。 斯型的なストレス潰癔の所見である。Figure 1 の左は周体下部後壁からの出血であり，右はレ ーザー照射により止血したところである。

Figure 2 の左は胃角部小弯からの出血であり, 右はレーザー照射により止助できた所見である。 このように，血管が露出していない出血は、レ ーザーで比較的容易に止血できる。

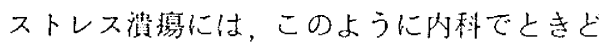
きみる精神的ストレスによる例のほかに，外科 側でよく問題になる手術侵態によるストレス渱 㰾がある。この場合はしばしば多量の出血を伴 うが，こういう例こそレーザー止血の最もよい 適応と考えている。すなわち手術後によきどき 遇遇するストレス貲舅による大出欰例では，往 々にして患者の全身状態が瑟いし，それに止血 対策として胃切除術の必要に迫られたとしても， そのための周切除そのものがまたストスとな り，他の消化管に新たなストレス潰湐の発生を きたす可能性があるわけで，外科側として処置 の判断に苦しむ例がある。このような場合，い ちかばちか，ともかく一時的にでもレーザー治 療で止血させ，全身状態の改善を持って手術に むっていくか，幸にしてそのまま手術せずにす めばそれにこしたことはない。こうしたレーザ 一の使用によって将来緊急手術の频度を減らす ことができれば，本療法の意義は大きいわのと 考穴る。

症例 2.42藏, 男性, 胃潰瘍

吐血にて来院し，内視鏡榆㚗を行ったところ，

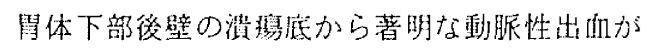
䜑められた（Figure 3)。これにレーザー照射 を行い，一時止向できたが，12時間後に再出向们 したため手術を推行した。切除鰝標本では，血

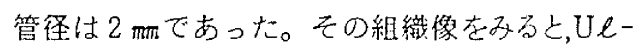

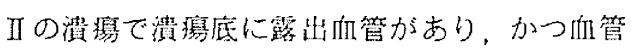
壁の变性，血管腔の狭小化，内腔の血栓形成に よる閉塞などの所見が認めら机た(Figure 4)。 この所見は十分ではないが，レーザーの効果が 得られているものと思う。本例の場合，血管径 が 2 m的かったこと，用いたフ ィイバースコ ープが直視型のため十分思うように照射できな かったことなどが，完全止血の得られなかった 理由と考えられる。例視型レーザー内視鏡の必 要性を感じた例である。この症例のように，動 脈性出扣の婸合，現段陆では $100 \%$ ，確实に止 欰できるとはいえない。そこでレーザーと他の 止血法との組み合わせによって，より確実な此 向效果を得ようと現在，いろいろ梌部中である が，その一つを，参考吉てに述でて扎うう。 
V 高張ナトリウム・エピネフリン局 注療法との併用

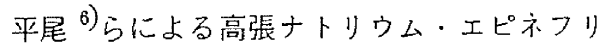
ン局注撩法とレーザー照射との併用は，本局注 療法により，噴出するような動脈性出血の出血 量や出血速度を一時的に低下させ，その間にレ ーザーを照射し，完全に止血させようというあ のである。その基整的検討結果を述べる。

Figure 5 の左は，イヌに〜゚゚ンを静注後， 鉗子にて粘膜出血を起こさせ，それにレーザー を照射し，右は止血したところである。

Figure 6 の上段左は，同様に出血させたとこ ろであり，上段右は，高張ナトリウム・エピネ フリン液局注1 分後の所見である。これにより 出血量は減少し，出的部周辺粘膜が血のため 白色に変化している。下段は，さらにレーザー 照射により，きれいに止血した所見を示してい る。この実験成績をFigure 7 人に示したが，レ

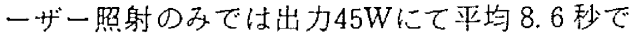
止血するのに対して，併用療法では平均 5.1 秒 で止血し，すぐれた結果を得た。このように一 層確実な止血效果をうるための，理々の工夫も 今後の課題である。

\section{$\mathrm{V}$ むすび}

以上レーザー内視鏡の消化管出血に対する止 血効果について述べてきたが，最近，われわれ は,より高出力の米国MOLECTRON社のYAG
レーザーを使用しており，また，通常の侧視型 ファイバーである $\mathrm{GF}-\mathrm{B}_{2} ， \mathrm{GF}-\mathrm{B}_{3}$ にも使用 できるクォーツフっイバーを試作したので，今 後，よりいっそう消化管出血における止欰效果 はあがると思われる。

\section{文献}

1）原田一道，他：レーザーコアグレーターの 基整的検討之臨休への応用。Gastroenterological Endoscopy 21:778 779, 1979

2）水帛和雄，他：レーザーコアグレーターの 基確的検討。Gastroenterological Endoscopy 21:938 947, 1979

3）水碧和雄，他：YAGレーザーの臨休への応 用(第2 報)。Gastroenterological Endoscopy 21:1289 1295, 1979

4）原田一道，他：最近経験したOsler 病の一 例ーレーザーコアグレーターによる止任対 策を含めて一G。astroenterological Endoscopy 22:400 404, 1980

5）原田一道，他：レーダーコアグレーターの 救急医療における意義。救急殹療 $1 ： 46$ 49,1980

6) 平尾雅紀, 他：高張 $\mathrm{Na}-$ Epinephrine 液 (HS-E) 局过潦法。胃と腸 15:751 755, 1980 


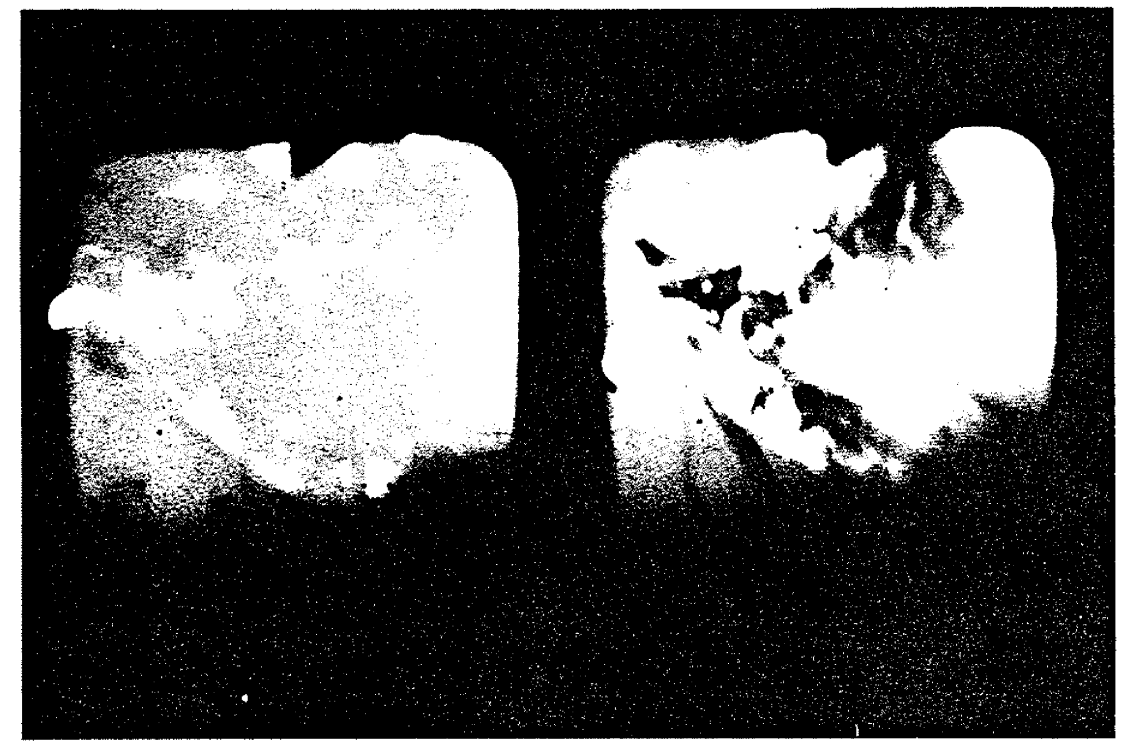

Figure 1

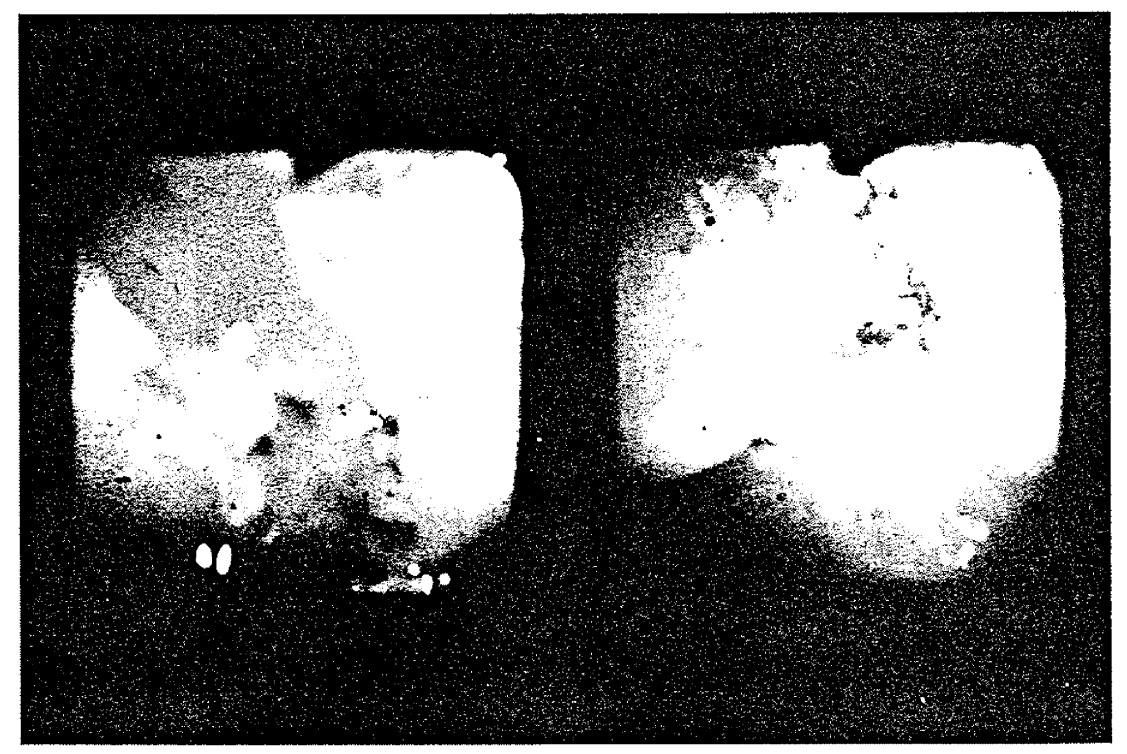

Figure 2 


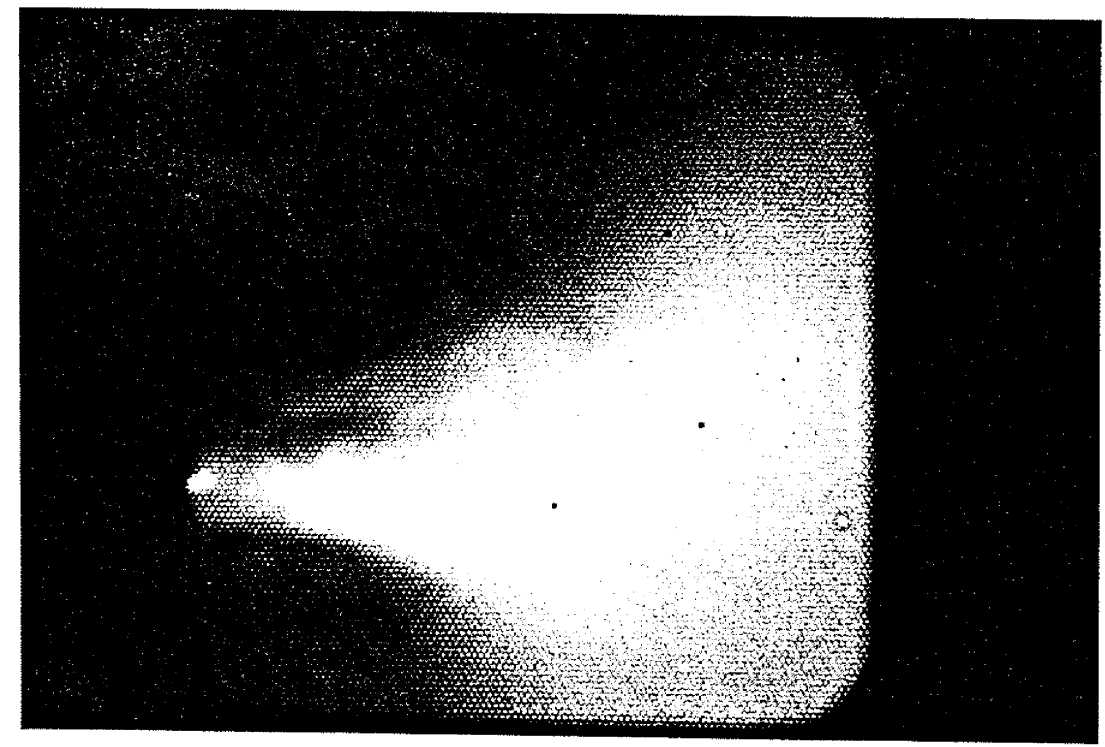

Figure 3

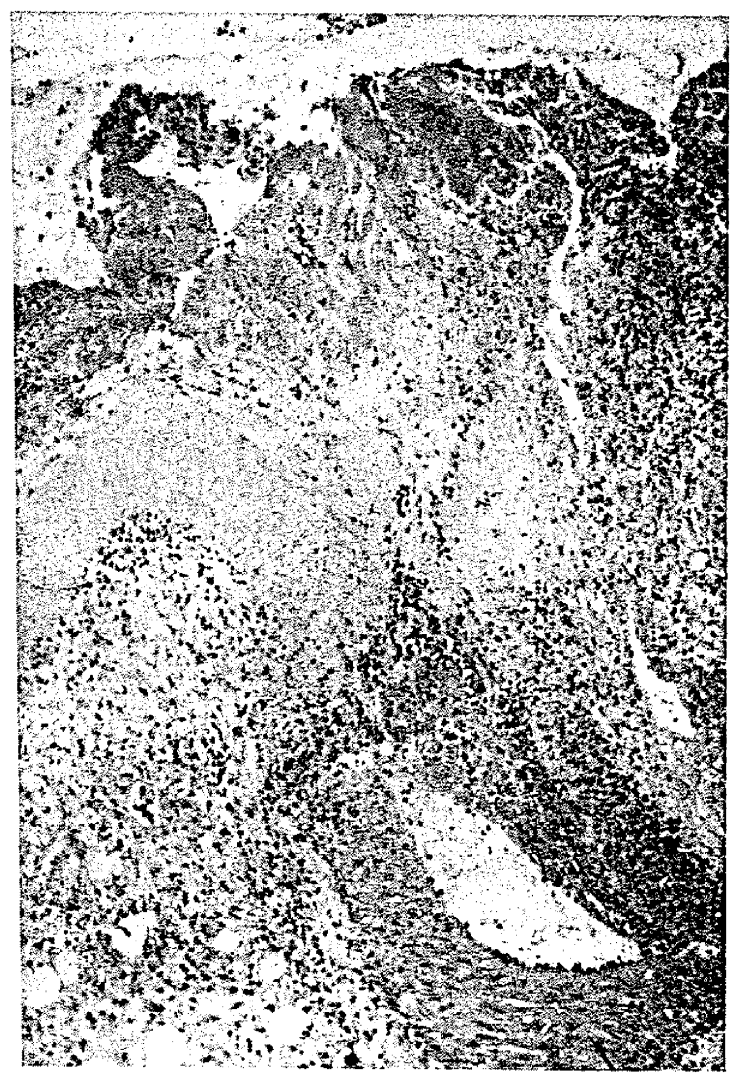

Figure 4 


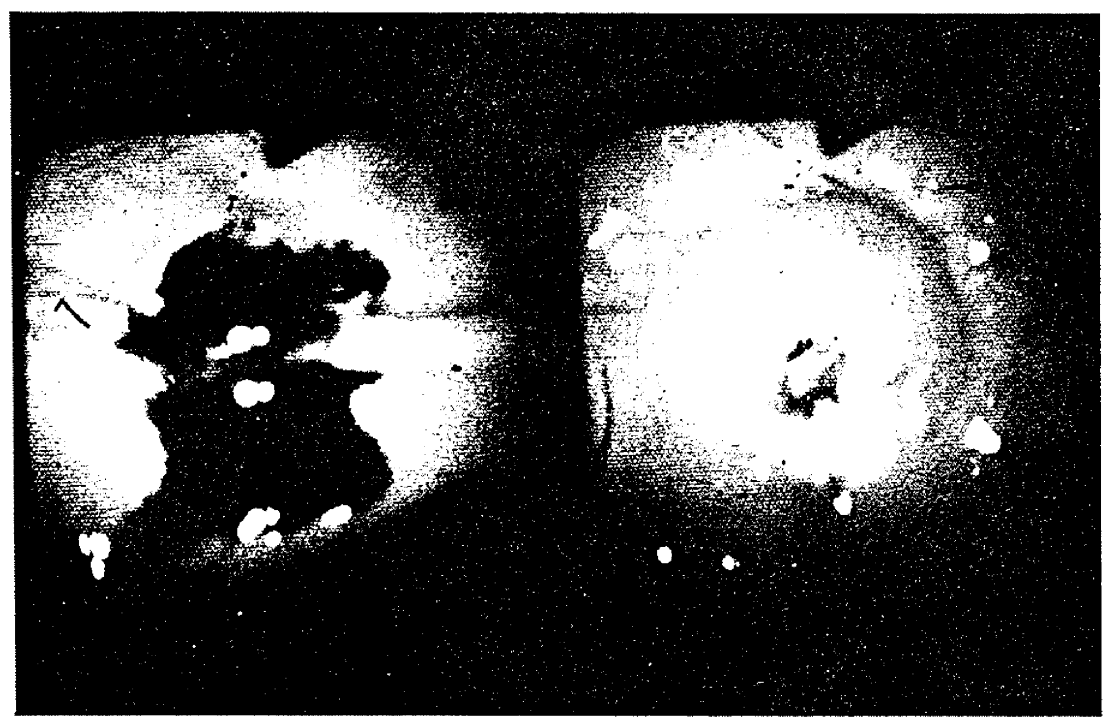

Figure 5

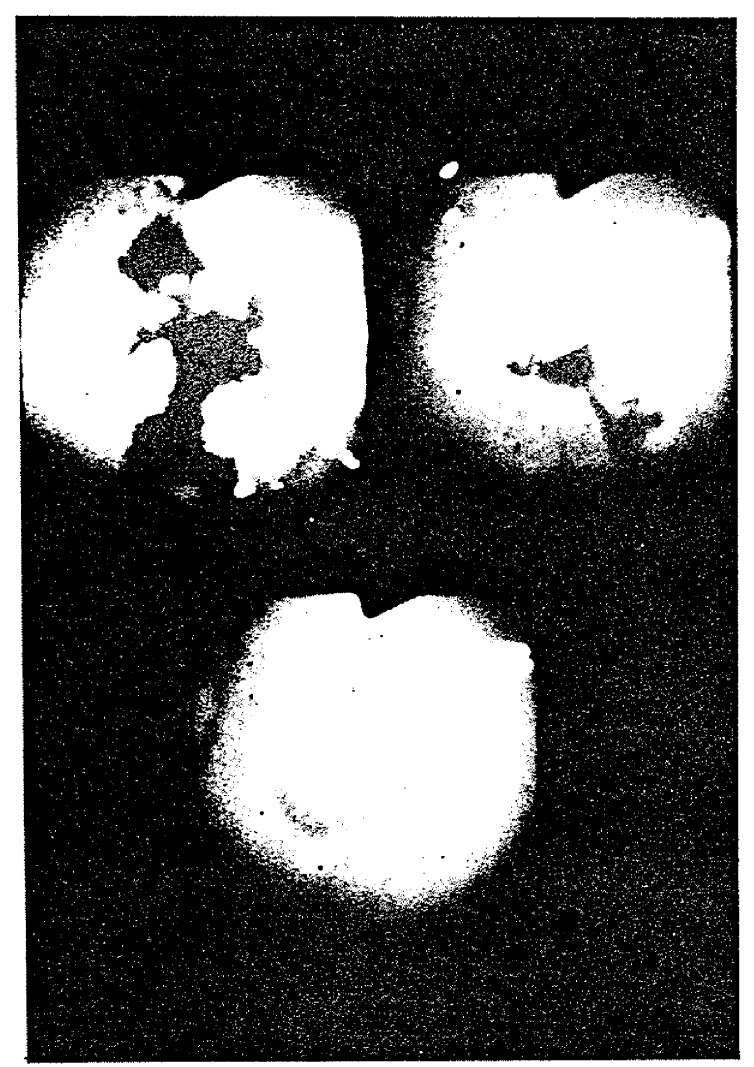

Figure 6 
Comparison of the coagulation effect between only laser and laser with local injection of sodium and epinephrine

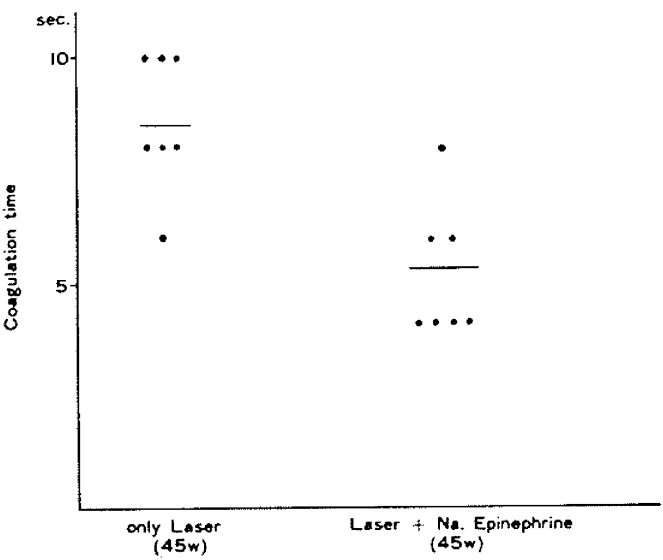

Figure 7 